\title{
Characterization of the complete mitochondrial genome of Spirocerca lupi: sequence, gene organization and phylogenetic implications
}

\author{
Guo-Hua Liu' ${ }^{1,2}$, Yan Wang ${ }^{2,3}$, Hui-Qun Song ${ }^{2}$, Ming-Wei Li ${ }^{4}$, Lin Ai ${ }^{5}$, Xing-Long Yu ${ }^{1 *}$ and Xing-Quan Zhu $u^{2,1^{*}}$
}

\begin{abstract}
Background: Spirocerca lupi is a life-threating parasitic nematode of dogs that has a cosmopolitan distribution but is most prevalent in tropical and subtropical countries. Despite its veterinary importance in canids, the epidemiology, molecular ecology and population genetics of this parasite still remain unexplored.

Methods: The complete mitochondrial (mt) genome of S. lupi was amplified in four overlapping long fragments using primers designed based on partial cox1, rrnS, cox2 and nad2 sequences. Phylogenetic re-construction of 13 spirurid species (including S. lupi) was carried out using Bayesian inference (BI) based on concatenated amino acid sequence datasets.

Results: The complete mt genome sequence of $\mathrm{S}$. lupi is $13,780 \mathrm{bp}$ in length, including 12 protein-coding genes, 22 transfer RNA genes and two ribosomal RNA genes, but lacks the atp8 gene. The gene arrangement is identical to that of Thelazia callipaeda (Thelaziidae) and Setaria digitata (Onchocercidae), but distinct from that of Dracunculus medinensis (Dracunculidae) and Heliconema longissimum (Physalopteridae). All genes are transcribed in the same direction and have a nucleotide composition high in A and T. The content of A $+\mathrm{T}$ is $73.73 \%$ for S. lupi, in accordance with $\mathrm{mt}$ genomes of other spirurid nematodes sequenced to date. Phylogenetic analyses using concatenated amino acid sequences of the 12 protein-coding genes by BI showed that the S. lupi (Thelaziidae) is closely related to the families Setariidae and Onchocercidae.

Conclusions: The present study determined the complete $\mathrm{mt}$ genome sequence of S. lupi. These new mt genome dataset should provide novel mtDNA markers for studying the molecular epidemiology and population genetics of this parasite, and should have implications for the molecular diagnosis, prevention and control of spirocercosis in dogs and other canids.
\end{abstract}

Keywords: Spirocerca lupi, Spirocercosis, Mitochondrial genome, Gene organization, Phylogenetic implication

\section{Background}

The nematode Spirocerca lupi (Rudolphi, 1809) (at the adult stage) parasitizes the oesophagus and aorta of canids, especially in dogs. S. lupi is responsible for canine spirocercosis with a worldwide distribution but is usually found in tropical and subtropical countries [1,2]. Canine spirocercosis is usually associated with several clinical signs, such as regurgitation, vomiting and dyspnoea $[3,4]$. This disease is also fatal when it causes

\footnotetext{
*Correspondence: xlyu999@yahoo.com.cn; xingquanzhu1@hotmail.com ${ }^{1}$ College of Veterinary Medicine, Hunan Agricultural University, Changsha, Hunan Province 410128, China

Full list of author information is available at the end of the article
}

malignant neoplasms or aortic aneurysms [2,4,5]. Fortunately, spirocercosis can be treated efficiently using anthelminthics, such as doramectin [6].

Canine spirocercosis caused by $S$. lupi is often neglected and underestimated by some veterinary scientists and practitioners. However, S. lupi is most prevalent in dogs in rural areas, such as in Bangladesh (40\%) [7], Greece (10\%) [8], Grenada ( $8.8 \%$ in owned dogs and $14.2 \%$ in stray dogs) [1], India (23.5\%) [9], Iran (19\%) [10], South Africa (13\%) [11] and Kenya (85\% in stray dogs and $38 \%$ in owned dogs) [12]. S. lupi has been also reported in dogs in China, with a very high prevalence (78.6\%) [13]. Although canine spirocercosis is an emerging disease, little is known about

\section{Biomed Central}

(c) 2013 Liu et al.; licensee BioMed Central Ltd. This is an Open Access article distributed under the terms of the Creative Commons Attribution License (http://creativecommons.org/licenses/by/2.0), which permits unrestricted use, distribution, and reproduction in any medium, provided the original work is properly cited. 
the molecular biology and genetics of S. lupi [14]. A previous study has found utility of mitochondrial (mt) cytochrome $c$ oxidase subunit $1(\operatorname{cox} 1)$ for population genetic and phylogenetic studies of S. lupi [14], yet, there is still a paucity of information on $S$. lupi mt genomics.

mt genome sequences provide useful genetic markers not only for genetic and epidemiological investigations and molecular identification of parasites, but also for phylogenetic and population studies [15-18] due to its maternal inheritance, rapid evolutionary rate, and lack of recombination $[19,20]$. To date, although mt genome sequences have been sequenced for 12 species within the order Spirurida, only one mt genome (for Thelazia callipaeda) is available within the family Thelaziidae [21]. Therefore, the objectives of the present study were to determine the complete $\mathrm{mt}$ genome sequence of $S$. lupi and to assess the phylogenetic position of this nematode in relation to other spirurid nematodes for which complete mt sequence datasets are available.

\section{Methods}

Ethics statement

This study was approved by the Animal Ethics Committee of Lanzhou Veterinary Research Institute, Chinese

Table 1 Sequences of primers used to amplify PCR fragments from Spirocerca lupi

\begin{tabular}{|c|c|}
\hline Name of primer & Sequence $\left(5^{\prime}\right.$ to $\left.3^{\prime}\right)$ \\
\hline \multicolumn{2}{|l|}{ Short-PCR } \\
\hline \multicolumn{2}{|l|}{ For $\operatorname{cox} 1$} \\
\hline JB3 & गाITGGGCATCCTGAGGTITAT \\
\hline JB4.5 & TAAAGAAAGAACATAATGAAAATG \\
\hline \multicolumn{2}{|l|}{ For $\operatorname{cox} 2$} \\
\hline SLCO2F & TTGAAATTACGAGTATGGGGATA \\
\hline SLCO2R & AGCTCCACAAATTTCTGAACACT \\
\hline \multicolumn{2}{|l|}{ For nad2 } \\
\hline SLND2F & TGGTGGAGGGGTITGTTATTTG \\
\hline SLND2R & ATCTTCTCAACCTGACGACC \\
\hline \multicolumn{2}{|l|}{ For rrns } \\
\hline SL12SF & AATCAAAATTTATTAGTTCGGGAGT \\
\hline SL12SR & AATTACTTाПTTCCAACTTCAA \\
\hline \multicolumn{2}{|l|}{ Long-PCR } \\
\hline SLCO1F & CाTAGGTGGMTGAGAGGTATTGTT \\
\hline SL12S R & CTTCATAAACCAAATATCTATCTGT \\
\hline SL12SF & ATAGATATTTGGTITATGAAGATTT \\
\hline SLCO2R & AAGAATGAATAACATCCGAAGAAGT \\
\hline SLCO2F & CCTATTGTTGGCTTATTTATGGTCAG \\
\hline SLND2R & CAAAAATGAAAAGGTGCCGAACCAGAT \\
\hline SLND2F & GGTITGGTCGTCAGGTTGAGAAGA \\
\hline SLCO1R & ATCATAGTAGCCGCCCTAAAATAAGTA \\
\hline
\end{tabular}

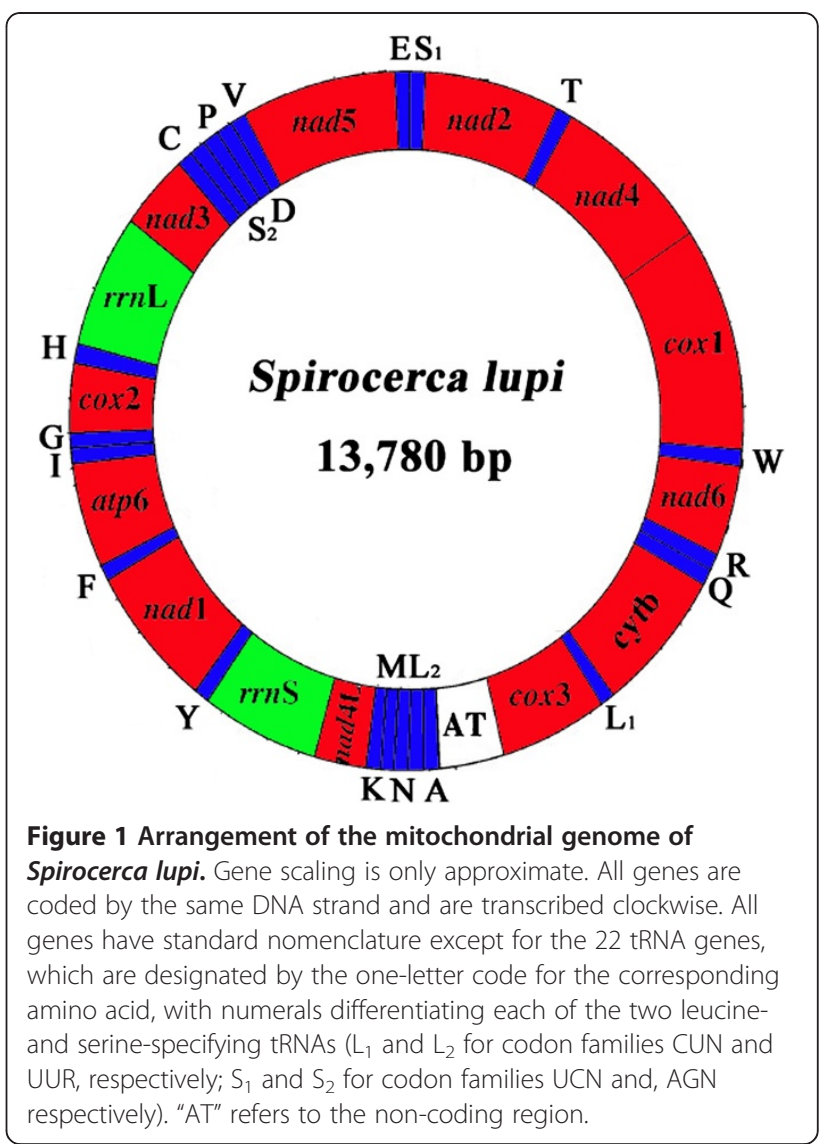

Academy of Agricultural Sciences (Approval No. LVRIAEC2010-007). The farmed dog from which S. lupi adults were collected, was handled in accordance with good animal practices required by the Animal Ethics Procedures and Guidelines of the People's Republic of China.

\section{Parasites and DNA extraction}

Adult nematodes representing $S$. lupi were obtained at post mortem from the oesophagus of an infected farmed dog in Zhanjiang, Guangdong province, China. These specimens were washed in physiological saline, identified morphologically to species according to existing descriptions [22], fixed in $70 \%(\mathrm{v} / \mathrm{v})$ ethanol and stored at $-20^{\circ} \mathrm{C}$ until use.

Total genomic DNA was isolated from one S. lupi worm using sodium dodecyl sulphate/proteinase $\mathrm{K}$ treatment, followed by spin-column purification (TIANamp Genomic DNA kit). In order to independently verify the identity of this specimen, the mt cox 1 gene was amplified by the polymerase chain reaction (PCR) and sequenced according to an established method [14]. The cox 1 sequence of this $S$. lupi sample had $96.5 \%$ similarity with that of S. lupi in dogs in South Africa (GenBank accession no. HQ674759). 


\section{Amplification and sequencing of partial $\operatorname{cox} 1, \operatorname{rrnS}, \operatorname{cox} 2$ and nad 2 genes}

Initially, a fragment of cox1 (346 bp) was amplified by conserved primers JB3/JB4.5 [23], and rrnS (213 bp), cox2 (300 bp) and nad2 (1200 bp) were amplified by PCR with primers designed (Table 1) based on sequences well conserved in many related taxa. PCR reactions $(25 \mathrm{~mL})$ were performed in $10 \mathrm{mM}$ Tris- $\mathrm{HCl}(\mathrm{pH} 8.4), 50 \mathrm{mM}$ $\mathrm{KCl}, 4 \mathrm{mM} \mathrm{MgCl} 2,200 \mathrm{mM}$ each of dNTP, $50 \mathrm{pmol}$ of each primer and $2 \mathrm{U}$ Taq polymerase (Takara) in a thermocycler (Biometra) under the following conditions: after an initial denaturation at $94^{\circ} \mathrm{C}$ for $5 \mathrm{~min}$, then $94^{\circ} \mathrm{C}$

Table 2 Mitochondrial genome organization of Spirocerca lupi

\begin{tabular}{|c|c|c|c|c|c|c|}
\hline Gene/region & Positions & Size (bp) & Number of $a a^{a}$ & Ini/Ter codons & Anticodons & In \\
\hline $\operatorname{cox} 1$ & $1-1650$ & 1650 & 549 & ATG/TAA & & +7 \\
\hline tRNA-Trp (W) & $1657-1714$ & 58 & & & TCA & +6 \\
\hline nad6 & $1751-2209$ & 459 & 152 & TTG/TAA & & +36 \\
\hline tRNA-Arg (R) & $2207-2266$ & 60 & & & ACG & -3 \\
\hline tRNA-GIn (Q) & $2263-2316$ & 54 & & & TTG & -4 \\
\hline cytb & $2315-3397$ & 1083 & 360 & ATT/TAA & & -2 \\
\hline tRNA-LeuCUN $\left(\mathrm{L}_{1}\right)$ & $3396-3450$ & 55 & & & TAG & -2 \\
\hline $\operatorname{cox} 3$ & $3448-4230$ & 783 & 260 & ATA/TAA & & -3 \\
\hline Non-coding region & $4231-4630$ & 400 & & & & 0 \\
\hline tRNA-Ala (A) & $4631-4692$ & 62 & & & TGC & 0 \\
\hline tRNA-LeuUUR $\left(L_{2}\right)$ & $4689-4742$ & 54 & & & TAA & -4 \\
\hline tRNA-Asn (N) & $4747-4804$ & 58 & & & $\mathrm{GTT}$ & +4 \\
\hline tRNA-Met (M) & $4807-4864$ & 58 & & & CAT & +2 \\
\hline tRNA-Lys (K) & $4867-4924$ & 58 & & & $\pi T$ & +2 \\
\hline nad4L & $4932-5159$ & 228 & 75 & ATG/TAG & & +7 \\
\hline$r r n s$ & $5170-5855$ & 686 & & & & +10 \\
\hline tRNA-Tyr $(Y)$ & $5855-5910$ & 56 & & & GTA & -1 \\
\hline nad1 & $5908-6816$ & 909 & 302 & TTG/TAA & & -3 \\
\hline tRNA-Phe (F) & $6785-6843$ & 59 & & & TTG & -32 \\
\hline atp6 & $6847-7431$ & 585 & 194 & ATT/TAG & & +3 \\
\hline tRNA-Ile (I) & 7435-7491 & 57 & & & GAT & +3 \\
\hline tRNA-Gly (G) & $7492-7546$ & 55 & & & TCC & 0 \\
\hline $\cos 2$ & $7549-8253$ & 705 & 234 & ATG/TAG & & +2 \\
\hline tRNA-His (H) & $8244-8302$ & 59 & & & GTG & -10 \\
\hline$r r n L$ & $8301-9288$ & 988 & & & & -2 \\
\hline nad3 & $9281-9616$ & 336 & 111 & TTG/TAA & & -8 \\
\hline tRNA-Cys (C) & $9616-9670$ & 55 & & & GCA & -1 \\
\hline tRNA-SerUCN $\left(S_{2}\right)$ & 9673-9726 & 54 & & & TGA & +2 \\
\hline tRNA-Pro (P) & $9730-9787$ & 58 & & & AGG & +3 \\
\hline tRNA-Asp (D) & $9847-9900$ & 54 & & & GTC & +59 \\
\hline tRNA-Val (V) & $9902-9955$ & 54 & & & TAC & +1 \\
\hline nad5 & 9959-11551 & 1593 & 530 & TTG/TAG & & +3 \\
\hline tRNA-Glu (E) & 11550-11606 & 57 & & & $\pi C$ & -2 \\
\hline tRNA-SerAGN $\left(S_{1}\right)$ & 11607-11656 & 50 & & & TCT & 0 \\
\hline nad2 & $11637-12485$ & 849 & 282 & ATG/TAG & & -20 \\
\hline tRNA-Thr (T) & $12487-12543$ & 57 & & & TGT & -1 \\
\hline nad4 & $12544-13773$ & 1230 & 409 & TTG/TAG & & 0 \\
\hline
\end{tabular}

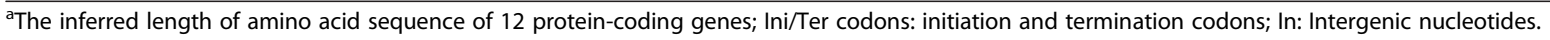


for $30 \mathrm{~s}$ (denaturation), $55^{\circ} \mathrm{C}$ (for $\operatorname{cox} 1$ ) or $48^{\circ} \mathrm{C}$ (for $\operatorname{cox} 2$ ) or $50^{\circ} \mathrm{C}$ (for $n a d 2$ and $r r n S$ ) for $30 \mathrm{~s}$ (annealing), $72^{\circ} \mathrm{C}$ for 1 min (extension) for 36 cycles, followed by $72^{\circ} \mathrm{C}$ for $10 \mathrm{~min}$ (final extension). Two microliters (5-10 ng) of genomic DNA was added to each PCR reaction. Each amplicon $(5 \mu \mathrm{L})$ was examined by agarose gel electrophoresis to validate amplification efficiency. Then, these amplicons were sent to Sangon Company (Shanghai, China) for sequencing from both directions by using primers used in PCR amplifications.

\section{Long-PCR amplification and sequencing}

After we had obtained partial cox $1, r r n S$, cox 2 and $n a d 2$ sequences for the $S$. lupi, we then designed four primers (Table 1) in the conserved regions to amplify the entire $\mathrm{mt}$ genome of $S$. lupi from this representative sample in four overlapping long fragments between cox1 and $r r n S$ (approximately $4.5 \mathrm{~kb}$ ), between $\mathrm{rrnS}$ and cox 2 (approximately $2.5 \mathrm{~kb}$ ), between cox 2 and nad2 (approximately $4 \mathrm{~kb}$ ), and between $\operatorname{nad} 2$ and $\operatorname{cox} 1$ (approximately $3 \mathrm{~kb}$ ). Long-PCR reactions $(25 \mu \mathrm{l})$ were performed in $2 \mathrm{mM}$

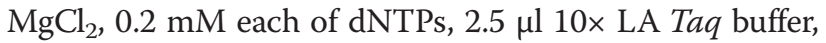
$2.5 \mu \mathrm{M}$ of each primer, $1.25 \mathrm{U}$ LA Taq polymerase (Takara), and $2 \mu \mathrm{l}$ of DNA sample in a thermocycler (Biometra) under the following conditions: $92^{\circ} \mathrm{C}$ for $2 \mathrm{~min}$ (initial denaturation), then $92^{\circ} \mathrm{C}$ for $10 \mathrm{~s}$ (denaturation), $60^{\circ} \mathrm{C}$ (for $4.5 \mathrm{~kb}$ ) or $44^{\circ} \mathrm{C}$ (for $2.5 \mathrm{~kb}$ ) or $52^{\circ} \mathrm{C}$ (for $4 \mathrm{~kb}$ ) or $48^{\circ} \mathrm{C}$ (for $3 \mathrm{~kb}$ fragment) for $30 \mathrm{~s}$ (annealing), and $60^{\circ} \mathrm{C}$ for
$10 \mathrm{~min}$ (extension) for 10 cycles, followed by $92^{\circ} \mathrm{C}$ for $10 \mathrm{~s}, 60^{\circ} \mathrm{C}$ (for $4.5 \mathrm{~kb}$ ) or $44^{\circ} \mathrm{C}$ (for $2.5 \mathrm{~kb}$ ) or $52^{\circ} \mathrm{C}$ (for $4 \mathrm{~kb}$ ) or $48^{\circ} \mathrm{C}$ (for $3 \mathrm{~kb}$ fragment) for $30 \mathrm{~s}$ (annealing), and $60^{\circ} \mathrm{C}$ for $10 \mathrm{~min}$ for 20 cycles, with a cycle elongation of $10 \mathrm{~s}$ for each cycle and a final extension at $60^{\circ} \mathrm{C}$ for $10 \mathrm{~min}$. Each PCR reaction yielded a single band detected in a $0.8 \%(\mathrm{w} / \mathrm{v})$ agarose gel (not shown). PCR products were sent to Sangon Company (Shanghai, China) for sequencing using a primer-walking strategy.

\section{Sequence analyses}

Sequences were assembled manually using the commercial software ContigExpress program of the Vector NTI software package version 6.0 (Invitrogen, Carlsbad, CA), and aligned against the complete $\mathrm{mt}$ genome sequences of other spirurid nematodes available using the computer program Clustal X 1.83 [24] and MegAlign procedure within the DNAStar 5.0 [25] to infer gene boundaries. The openreading frames were analysed with Open Reading Frame Finder (http://www.ncbi.nlm.nih.gov/gorf/gorf.html) using the invertebrate mitochondrial code, and subsequently compared with that of T. callipaeda [21]. Protein-coding gene sequences were translated into amino acid sequences using the invertebrate mitochondrial genetic code; amino acid sequences were aligned using default settings with MEGA 5.0 [26]. Translation initiation and termination codons were identified by comparison with those of the spirurid nematodes reported previously [21,27]. For

Table 3 Comparison of A + T content (\%) of gene and region of the $\mathrm{mt}$ genomes of spirurid nematodes sequenced to date (alphabetical order), including Spirocerca lupi (in bold)

\begin{tabular}{|c|c|c|c|c|c|c|c|c|c|c|c|c|c|}
\hline Gene/region & AV & $\mathrm{BM}$ & $\mathrm{CQ}$ & DI & DM & $\mathrm{HL}$ & LL & OF & OV & SD & SL & $\mathrm{TC}$ & WB \\
\hline atp6 & 75.21 & 75.09 & 80.14 & 71.88 & 72.40 & 77.89 & 76.46 & 73.71 & 72.99 & 74.23 & 74.87 & 74.23 & 76.63 \\
\hline $\operatorname{cox} 1$ & 67.36 & 68.98 & 70.28 & 67.88 & 68.21 & 71.69 & 69.48 & 69.70 & 67.03 & 69.10 & 66.97 & 67.88 & 67.70 \\
\hline $\operatorname{cox} 2$ & 66.81 & 68.96 & 73.25 & 69.15 & 68.25 & 74.71 & 71.53 & 68.10 & 69.24 & 69.38 & 68.51 & 67.38 & 70.57 \\
\hline $\operatorname{cox} 3$ & 71.54 & 72.69 & 76.92 & 71.79 & 71.54 & 75.93 & 76.20 & 72.18 & 71.79 & 72.56 & 71.39 & 72.41 & 74.33 \\
\hline cytb & 72.32 & 73.97 & 76.13 & 72.25 & 72.14 & 79.30 & 75.35 & 73.65 & 72.11 & 72.34 & 72.85 & 73.68 & 72.70 \\
\hline nad1 & 73.43 & 73.55 & 75.85 & 72.94 & 72.29 & 75.69 & 72.85 & 71.60 & 69.78 & 72.78 & 72.50 & 73.22 & 72.52 \\
\hline $\operatorname{nad} 2$ & 74.68 & 77.61 & 82.39 & 74.39 & 76.93 & 82.92 & 77.26 & 75.56 & 74.30 & 76.49 & 70.91 & 77.35 & 75.71 \\
\hline nad3 & 79.82 & 79.35 & 81.71 & 77.15 & 75.89 & 83.18 & 79.82 & 76.56 & 76.11 & 77.06 & 80.65 & 80.24 & 84.27 \\
\hline nad4 & 73.98 & 76.31 & 78.05 & 74.55 & 72.32 & 80.36 & 75.75 & 74.05 & 73.15 & 76.91 & 74.47 & 75.59 & 73.88 \\
\hline nad4L & 76.89 & 82.08 & 83.33 & 77.37 & 74.39 & 82.05 & 81.09 & 77.73 & 78.60 & 76.76 & 76.75 & 80.17 & 80.66 \\
\hline nad5 & 71.93 & 74.81 & 78.17 & 73.75 & 73.64 & 78.93 & 74.03 & 73.62 & 72.87 & 74.81 & 72.88 & 73.82 & 74.69 \\
\hline nad6 & 77.19 & 81.46 & 82.89 & 80.57 & 76.26 & 81.74 & 81.98 & 81.11 & 79.11 & 82.44 & 77.56 & 80.17 & 80.04 \\
\hline$r r n s$ & 75.48 & 76.04 & 76.85 & 75.84 & 73.59 & 80.50 & 76.56 & 75.84 & 74.71 & 74.55 & 76.09 & 75.68 & 75.30 \\
\hline$r r n L$ & 77.78 & 80.78 & 80.25 & 79.55 & 76.70 & 81.81 & 78.65 & 77.71 & 76.95 & 79.40 & 79.05 & 77.43 & 79.01 \\
\hline AT-loop & 83.37 & 85.11 & 86.49 & 85.91 & 74.75 & 96.75 & 83.68 & 79.93 & 85.32 & 86.36 & 88.50 & 79.57 & 83.71 \\
\hline Entire & 73.54 & 75.46 & 77.67 & 74.16 & 72.72 & 79.11 & 75.54 & 74.17 & 73.30 & 75.14 & 73.73 & 74.57 & 74.59 \\
\hline
\end{tabular}

*Nematodes: AV: Acanthocheilonema viteae, BM: Brugia malayi, CQ: Chandlerella quiscali, DI: Dirofilaria immitis, DM: Dracunculus medinensis, HL: Heliconema longissimum, LL: Loa loa, OF: Onchocerca flexuosa, OV: Onchocerca volvulus, SD: Setaria digitata, SL: Spirocerca lupi, TC: Thelazia callipaeda, WB: Wuchereria bancrofti, Entire: entire $\mathrm{mt}$ genome. 
analyzing ribosomal RNA genes, putative secondary structures of 22 tRNA genes were identified using tRNAscan-SE [28], of the 22 tRNA genes, 14 were identified using tRNAscan-SE, the other 8 tRNA genes were found by eye inspection, and rRNA genes were identified by comparison with that of spirurid nematodes $[21,27]$.

\section{Phylogenetic analysis}

The amino acid sequences conceptually translated from individual genes of the $\mathrm{mt}$ genome of $S$. lupi were concatenated. Selected for comparison were concatenated amino acid sequences predicted from published $\mathrm{mt}$ genomes of key nematodes representing the order Spirurida, including the superfamilies Thelazoidea ( $T$. callipaeda [21]), Filarioidea (Acanthocheilonema viteae [29], Brugia malayi [30], Chandlerella quiscali [29], Dirofilaria immitis [31], Loa loa [29], Onchocerca flexuosa [29], O. volvulus [32], S. digitata [27] and Wuchereria bancrofti [18]), Dracunculoidea (Dracunculus medinensis [33]) and Physalopteroidea (Heliconema longissimum [33]) (GenBank accession numbers JX069968, NC_016197, NC_004298, NC_014486, NC_005305, NC_016199, NC_0

Table 4 Codon usage of Spirocerca lupi mitochondrial protein-coding genes

\begin{tabular}{|c|c|c|c|c|c|c|c|}
\hline Amino acid & Codon & Number & Frequency (\%) & Amino acid & Codon & Number & Frequency (\%) \\
\hline Phe & $\pi T$ & 591 & 17.03 & Met & ATA & 52 & 1.49 \\
\hline Phe & $\pi \mathrm{TC}$ & 16 & 0.46 & Met & ATG & 103 & 2.96 \\
\hline Leu & TTA & 195 & 5.61 & Thr & $\mathrm{ACT}$ & 81 & 2.33 \\
\hline Leu & TTG & 235 & 6.77 & Thr & ACC & 3 & 0.08 \\
\hline Ser & TCT & 139 & 4.00 & Thr & ACA & 2 & 0.05 \\
\hline Ser & TCC & 7 & 0.20 & Thr & ACG & 3 & 0.08 \\
\hline Ser & TCA & 8 & 0.23 & Asn & AAT & 87 & 2.50 \\
\hline Ser & TCG & 6 & 0.17 & Asn & AAC & 6 & 0.17 \\
\hline Tyr & TAT & 214 & 6.16 & Lys & AAA & 42 & 1.21 \\
\hline Tyr & TAC & 6 & 0.17 & Lys & AAG & 56 & 1.61 \\
\hline Stop & TAA & 7 & 0.20 & Ser & AGT & 99 & 2.85 \\
\hline Stop & TAG & 5 & 0.14 & Ser & AGC & 5 & 0.14 \\
\hline Cys & TGT & 75 & 2.16 & Ser & AGA & 22 & 0.63 \\
\hline Cys & TGC & 3 & 0.08 & Ser & AGG & 30 & 0.86 \\
\hline Trp & TGA & 36 & 1.03 & Val & $\mathrm{GTT}$ & 239 & 6.88 \\
\hline Trp & TGG & 56 & 1.61 & Val & GTC & 5 & 0.14 \\
\hline Leu & $\mathrm{CTT}$ & 19 & 0.54 & Val & GTA & 35 & 1.00 \\
\hline Leu & CTC & 0 & 0 & Val & GTG & 37 & 1.06 \\
\hline Leu & CTA & 10 & 0.28 & Ala & $\mathrm{GCT}$ & 64 & 1.84 \\
\hline Leu & $\mathrm{CTG}$ & 2 & 0.05 & Ala & GCC & 4 & 0.11 \\
\hline Pro & $\mathrm{CCT}$ & 55 & 1.58 & Ala & GCA & 1 & 0.02 \\
\hline Pro & CCC & 7 & 0.20 & Ala & GCG & 10 & 0.28 \\
\hline Pro & CCA & 6 & 0.17 & Asp & GAT & 66 & 1.90 \\
\hline Pro & CCG & 9 & 0.25 & Asp & GAC & 2 & 0.05 \\
\hline His & CAT & 52 & 1.49 & Glu & GAA & 31 & 0.89 \\
\hline His & CAC & 1 & 0.02 & Glu & GAG & 42 & 1.21 \\
\hline Gln & CAA & 20 & 0.57 & Gly & GGT & 143 & 4.12 \\
\hline Gln & CAG & 31 & 0.89 & Gly & GGC & 12 & 0.34 \\
\hline Arg & CGT & 46 & 1.32 & Gly & GGA & 33 & 0.95 \\
\hline Arg & CGC & 1 & 0.02 & Gly & GGG & 72 & 2.07 \\
\hline Arg & CGA & 3 & 0.08 & lle & ATT & 212 & 6.10 \\
\hline Arg & CGG & 6 & 0.17 & lle & ATC & 4 & 0.11 \\
\hline
\end{tabular}


16172, AF015193, NC_014282, JN367461, NC_016019 and NC_016127, respectively), using Ascaris suum [34] (GenBank accession number HQ704901) as the outgroup. The amino acid sequences were aligned using Clustal X 1.83 [24] using default settings, ambiguously aligned regions were excluded using Gblocks online server (http://molevol.cmima.csic.es/castresana/Gblocks_server. html) using the options for a less stringent selection, and then subjected to phylogenetic analysis using Bayesian inference (BI) as described previously [35,36]. Phylograms were drawn using the Tree View program v.1.65 [37].

\section{Results and discussion}

\section{General features of the S. lupi mt genome}

The complete mtDNA sequence of $S$. lupi was $13,780 \mathrm{bp}$ in size (Figure 1), and has been deposited in the GenBank under the accession number KC305876. The mt genome of S. lupi contains 12 protein-coding genes (cox1-3, nad1-6, nad4L, atp6 and cytb), 22 transfer RNA genes, two ribosomal RNA genes ( $r r n \mathrm{~L}$ and $r r n S)$ and a non-coding (control or AT-rich) region, but lacks an atp8 gene (Table 2). All genes are transcribed in the same direction. The gene order is identical to those of $T$. callipaeda and S. digitata [21,27], but distinct from those of $H$. longissimum (rearrangement markedly) and Dracunculus medinensis (tRNA-Met and tRNA-Val change) [33]. The nucleotide compositions of S. lupi mt genome is biased toward $\mathrm{A}$ and $\mathrm{T}$, with $\mathrm{T}$ being the most favored nucleotide and $\mathrm{C}$ being the least favored, in accordance with $\mathrm{mt}$ genomes of other spirurid nematodes $[27,31]$. The content of $\mathrm{A}+\mathrm{T}$ is $73.73 \%$ for S. lupi, similar to that of $\mathrm{mt}$ genomes of other spirurid nematodes sequenced to date, such as that of T. callipaeda (74.57\%)
[21] and W. bancrofti (74.59\%) [18] (Table 3). Furthermore, the $S$. lupi mt genes overlap a total of 98 bp in 16 locations ranging from 1 to $32 \mathrm{bp}$ (Table 2). The longest is a 32 bp overlap between $\operatorname{nad} 1$ and tRNA-Phe. The mt genome of $S$. lupi has $150 \mathrm{bp}$ of intergenic regions at 16 locations ranging in size from $1 \mathrm{bp}$ to $59 \mathrm{bp}$, the longest intergenic region is a 59 bp between tRNA-Pro and tRNA-Asp (Table 2). The $\mathrm{mt}$ genome of $T$. callipaeda has 14 intergenic regions, which range from 1 to $62 \mathrm{bp}$ in length. The longest region is $62 \mathrm{bp}$ between tRNAPro and tRNA-Asp [21].

\section{Protein-coding genes}

The S. lupi mt genome encodes 12 protein-coding genes, which are identical to those of T. callipaeda and $S$. digitata $[21,27]$. For $S$. lupi, the sizes of the protein-coding genes were in the order: cox $1>\operatorname{nad} 5>\operatorname{nad} 4>\operatorname{cytb}>\operatorname{nad} 1>$ nad $2>\operatorname{cox} 3>\operatorname{cox} 2>\operatorname{atp} 6>\operatorname{nad} 6>\operatorname{nad} 3>\operatorname{nad} 4 \mathrm{~L}$ (Table 2). The predicted translation initiation and termination codons for the 12 protein-coding genes of S. lupi mt genome were compared with that of T. callipaeda and S. digitata [21,27]. The most common initiation codon for S. lupi is TTG (5 of 12 protein genes), followed by ATG (4 of 12 protein genes), ATT ( 2 of 12 protein genes) and ATA (1 of 12 protein genes) (Table 2). In this mt genome, all protein genes were predicted to have a TAA or TAG as termination codon (Table 2). Although incomplete termination codons ( $\mathrm{T}$ or TA) are present in some other nematodes, including Anisakis simplex (s. l.) [38], A. suum [39], Caenorhabditis elegans [39], S. digitata [27], Toxocara spp. [40] and Trichinella spiralis [41], they were not identified in the S. lupi mt genome.

Excluding the termination codons, a total of 3,458 amino acids of protein-coding genes are encoded by the

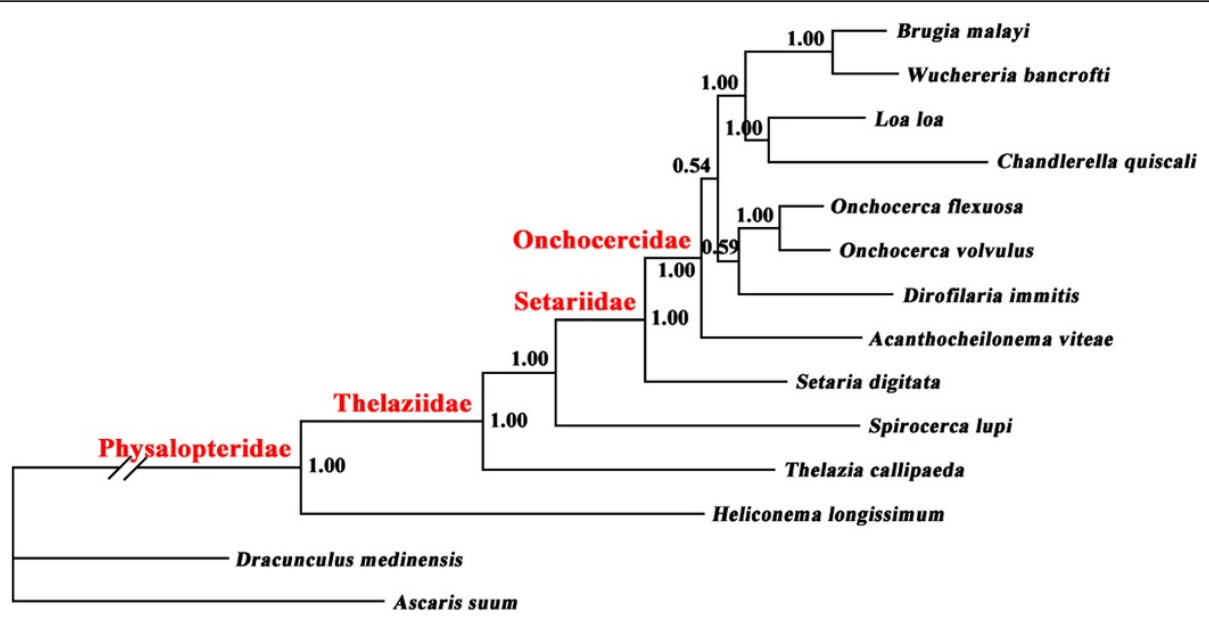

Figure 2 Relationship of Spirocerca lupi with other selected spirurid nematodes based on mitochondrial sequence data. The concatenated amino acid sequences of 12 protein-coding genes were subjected to analysis by Bayesian inference (BI) using Ascaris suum as the outgroup. Posterior probability (pp) values are indicated. 
S. lupi mt genome. Table 4 shows the codon usage. Condons composed of $\mathrm{A}$ and $\mathrm{T}$ are predominantly used, which seems to reflect the high $\mathrm{A}+\mathrm{T}$ content of the $\mathrm{mt}$ genome of S. lupi. A strong preference for $\mathrm{A}+\mathrm{T}$ rich codons usage is found in mtDNA of S. lupi. For example, the most frequently used amino acid was Phe (TTT: 17.03\%), followed by Leu (TTG: 6.77\%), Tyr (ATA: 6.16\%) and IIe (ATT: 6.10\%). This result is consistent with a recent study [21].

\section{Transfer RNA genes and ribosomal RNA genes}

The sizes of 22 tRNA genes identified in the $S$. lupi $\mathrm{mt}$ genome ranged from 50 to $62 \mathrm{bp}$ in size. Secondary structures predicted for the 22 tRNA genes of $S$. lupi (not shown) are similar to that of S. digitata [27]. The $r r n \mathrm{~L}$ and $r r n S$ genes of $S$. lupi were identified by comparison with the mt genomes of $T$. callipaeda and $S$. digitata. The $r r n \mathrm{~L}$ is located between tRNA-His and nad3, and rrnS is located between nad4L and tRNATyr. The lengths of the $r r n \mathrm{~L}$ and $r r n \mathrm{~S}$ genes were 988 bp and 686 bp for S. lupi, respectively (Table 2). The A $+\mathrm{T}$ contents of the $r r n \mathrm{~L}$ and $r r n S$ genes for $S$. lupi are $79.05 \%$ and $76.09 \%$, respectively.

\section{Non-coding regions}

The majority of nematode mtDNA sequences contain usually two non-coding regions of significant size difference, the long non-coding region and the short noncoding region, including $A$. lumbricoides and $A$. suum [34], Contracaecum rudolphii B [42], Oesophagostomum spp. [43], Toxocara spp. [40] and Trichuris spp. [44,45]. However, there is only one non-coding region (AT-rich region) in the mt genome of $S$. lupi, which is located between cox3 and tRNA-Ala (Figure 1 and Table 2), with $88.50 \% \mathrm{~A}+\mathrm{T}$ content (Table 3 ). This region of the $\mathrm{mt}$ genome of $S$. lupi was considered as a non-coding region (or AT-rich region) due to its location and AT rich feature based on comparison with those of spirurid nematodes reported previously [21,27]. Moreover, in the AT-rich region of $S$. lupi consecutive sequences $[\mathrm{A}]_{13}$ and $[\mathrm{T}]_{12}$ were found, but there are no AT dinucleotide repeat sequences similar to that of $A$. simplex s.l. and $S$. digitata in the this region $[27,38]$.

\section{Phylogenetic analyses}

The phylogenetic relationships of 12 spirurid species based on concatenated amino acid sequence datasets, plus the mtDNA sequence of $S$. lupi obtained in the present study, using BI is shown in Figure 2. The results revealed that $S$. lupi (Thelaziidae) was a sister taxon to a clade containing $S$. digitata (Setariidae) and other members of the Onchocercidae, including B. malayi and $D$. immitis (posterior probability $=1.00$ ), consistent with results of previous studies $[14,21,46]$.
Many studies have demonstrated that mtDNA sequences are valuable genetic markers for phylogenetic studies of members within the Nematoda. A recent study analyzed $\mathrm{mt}$ sequence variations in human- and pig-derived Trichuris and demonstrated that they represent separate species [44]. In addition, a previous study sequenced and compared the mt genomes of $A$. lumbricoides and A. suum from humans and pigs and indicted that $A$. lumbricoides and $A$. suum may represent the same species [34]. In the present study, the characterization of the $\mathrm{mt}$ genome of $S$. lupi can promote to reassess the systematic relationships within the order Spirurida using mt genomic datasets. For many years, there have been considerable debates about the phylogenetic position of members of spirurid nematodes $[47,48]$. Given this utility of mt genomic datasets, thus, further work should sequence more mt genomes of spirurid nematodes and re-construct the phylogenetic relationships of spirurid nematodes using expanded mt datasets.

\section{Conclusions}

The present study determined the complete mt genome sequence of $S$. lupi, and ascertained its phylogenetic position within the Spirurida. These new mtDNA data will provide useful novel markers for studying the molecular epidemiology and population genetics of $S$. lupi, and have implications for the diagnosis, prevention and control of spirocercosis in canid animals.

\section{Competing interests}

The authors declare that they have no competing interests.

\section{Authors' contributions}

$X Q Z$ and $X L Y$ conceived and designed the study, and critically revised the manuscript. GHL, YW and HQS performed the experiments, analyzed the data and drafted the manuscript. MWL and LA helped in study design, study implementation and manuscript revision. All authors read and approved the final manuscript.

\section{Acknowledgements}

This work was supported in part by the International Science \& Technology Cooperation Program of China (Grant No. 2013DFA31840), the Science Fund for Creative Research Groups of Gansu Province (Grant No. 1210RJIA006), the China Postdoctoral Science Foundation (Grant No. 2012 M520353) and the Shanghai Postdoctoral Sustentation Fund (Grant No. 12R21416500).

\section{Author details}

${ }^{1}$ College of Veterinary Medicine, Hunan Agricultural University, Changsha, Hunan Province 410128, China. ${ }^{2}$ State Key Laboratory of Veterinary Etiological Biology, Key Laboratory of Veterinary Parasitology of Gansu Province, Lanzhou Veterinary Research Institute, Chinese Academy of Agricultural Sciences, Lanzhou, Gansu Province 730046, China. ${ }^{3}$ College of Veterinary Medicine, South China Agricultural University, Guangzhou, Guangdong Province 510642, China. ${ }^{4}$ Department of Veterinary Medicine, Agricultural College, Guangdong Ocean University, Huguangyan, Zhanjiang, Guangdong Province 524088, China. ${ }^{5}$ National Institute of Parasitic Diseases, Chinese Center for Disease Control and Prevention, WHO Collaborating Center for Malaria, Schistosomiasis and Filariasis, Key Laboratory of Parasite and Vector Biology, Ministry of Health, Shanghai 200025, China.

Received: 24 January 2013 Accepted: 17 February 2013 Published: 22 February 2013 


\section{References}

1. Chikweto A, Bhaiyat MI, Tiwari KP, de Allie C, Sharma RN: Spirocercosis in owned and stray dogs in Grenada. Vet Parasitol 2012, 190:613-616.

2. van der Merwe LL, Kirberger RM, Clift S, Williams M, Keller N, Naidoo V: Spirocerca lupi infection in the dog: a review. Vet J 2008, 176:294-309.

3. Mazaki-Tovi M, Baneth G, Aroch I, Harrus S, Kass PH, Ben Ari T, Zur G, Aizenberg I, Bark H, Lavy E: Canine spirocercosis: clinical, diagnostic, pathologic and epidemiologic characteristics. Vet Parasitol 2002, 107:235-250.

4. Ranen E, Lavy E, Aizenberg I, Perl S, Harrus S: Spirocercosis associated esophageal sarcomas in dogs. A retrospective study of 17 cases (1997-2003). Vet Parasitol 2004, 119:209-221.

5. Rinas MA, Nesnek R, Kinsella JM, DeMatteo KE: Fatal aortic aneurysm and rupture in a neotropical bush dog (Speothos venaticus) caused by Spirocerca lupi. Vet Parasitol 2009, 164:347-349.

6. Lavy E, Aroch I, Bark H, Markovics A, Aizenberg I, Mazaki-Tovi M, Hagag A, Harrus S: Evaluation of doramectin for the treatment of experimental canine spirocercosis. Vet Parasitol 2002, 109:65-73.

7. Shubhagata D, Abdul A, Mohammad MH, Suchandan S, Muraduzzaman M: Spirocercosis in stray dogs of Chittagong Metropolitan area of Bangladesh: an epidemiological and pathological investigation. Vet World 2011, 4:485-491.

8. Mylonakis ME, Koutinas AF, Liapi MV, Saridomichelakis MN, Rallis TS: A comparison of the prevalence of Spirocerca lupi in three groups of dogs with different life and hunting styles. J Helminthol 2001, 75:359-361.

9. Ramachandran PV, Shakir SA, Ramakrishnan R: Spirocercosis in canines: a necropsy survey. Cheiron-Tamil Nadu J Vet Sci Anim Husbandry 1984, 13:132-135.

10. Oryan A, Sadjjadi SM, Mehrabani D, Kargar M: Spirocercosis and its complications in stray dogs in Shiraz, Southern Iran. Vet Med Czech 2008, 53:617-624.

11. Minnaar WN, Krececk RC, Fourie L: Helminthes of dogs from a peri-urban resource-limited community in free state province, South Africa. Vet Parasitol 2002, 107:343-349.

12. Brodey RS, Thompson RG, Sayer PD, Eugster B: Spirocerca lupi infection in dogs in Kenya. Vet Parasitol 1977, 3:49-59.

13. Jiang XL, Dai ZJ: Investigation of parasites in dogs in Sichuan province. Sichuan J Zool 1988, 7:9 (in Chinese).

14. Traversa D, Costanzo F, lorio R, Aroch I, Lavy E: Mitochondrial cytochrome c oxidase subunit 1 (cox1) gene sequence of spirocerca lupi (nematoda, spirurida): avenues for potential implications. Vet Parasitol 2007, 146:263-270.

15. Unnasch TR, Williams SA: The genomes of onchocerca volvulus. Int J Parasitol 2000, 30:543-552

16. Choi KS, Koekemoer LL, Coetzee M: Population genetic structure of the major malaria vector anopheles funestus s.s. and allied species in southern Africa. Parasit Vectors 2012, 5:283.

17. Gasser RB, Jabbar A, Mohandas N, Höglund J, Hall RS, Littlewood DT, Jex AR: Assessment of the genetic relationship between Dictyocaulus species from Bos taurus and Cervus elaphus using complete mitochondrial genomic datasets. Parasit Vectors 2012, 5:241.

18. Ramesh A, Small ST, Kloos ZA, Kazura JW, Nutman TB, Serre D, Zimmerman PA: The complete mitochondrial genome sequence of the filarial nematode Wuchereria bancrofti from three geographic isolates provides evidence of complex demographic history. Mol Biochem Parasitol 2012, 183:32-41.

19. Wolstenholme DR: Animal mitochondrial DNA, structure and evolution. Int Rev Cytol 1992, 141:173-216.

20. Boore JL: Animal mitochondrial genomes. Nucleic Acids Res 1999, 27:1767-1780.

21. Liu GH, Gasser RB, Otranto D, Xu MJ, Shen JL, Mohandas N, Zhou DH, Wang Y, Zhu XQ: Mitochondrial genome of the eyeworm, thelazia callipaeda (nematoda: spirurida), as the first representative from the family thelaziidae. PLoS Negl Trop Dis 2013, 7:e2029.

22. Skrjabin Kl: Key to parasitic nematodes, Spirurata and Filariata, Volume 1. Moscow: Academy of Sciences USSR; 1969.

23. Gasser RB, Zhu XQ, McManus DP: NADH dehydrogenase subunit 1 and cytochrome c oxidase subunit I sequences compared for members of the genus taenia (cestoda). Int J Parasitol 1999, 29:1965-1970.

24. Thompson JD, Gibson TJ, Plewniak F, Jeanmougin F, Higgins DG: The Clustal X windows interface: flexible strategies for multiple sequence alignment aided by quality analysis tools. Nucleic Acids Res 1997, 24:4876-4882.

25. Burland TG: DNASTAR's Lasergene sequence analysis software. Meth $\mathrm{Mol}$ Biol 2000, 132:71-91.

26. Tamura K, Peterson D, Peterson N, Stecher G, Nei M, Kumar S: MEGA5: molecular evolutionary genetics analysis using maximum likelihood, evolutionary distance, and maximum parsimony methods. Mol Biol Evol 2011, 28:2731-2739.

27. Yatawara L, Wickramasinghe S, Rajapakse RP, Agatsuma T: The complete mitochondrial genome of Setaria digitata (Nematoda: Filarioidea): Mitochondrial gene content, arrangement and composition compared with other nematodes. Mol Biochem Parasitol 2010, 173:32-38.

28. Lowe TM, Eddy SR: TRNAscan-SE: a program for improved transfer RNA detection in genomic sequence. Nucleic Acids Res 1997, 25:955-964.

29. McNulty SN, Mullin AS, Vaughan JA, Tkach W, Weil GJ, Fischer PU: Comparing the mitochondrial genomes of Wolbachia-dependent and independent filarial nematode species. BMC Genomics 2012, 13:145.

30. Ghedin E, Wang S, Spiro D, Caler E, Zhao Q, Crabtree J, Allen JE, Delcher AL, Guiliano DB, Miranda-Saavedra D, Angiuoli SV, Creasy T, Amedeo P, Haas B, El-Sayed NM, Wortman JR, Feldblyum T, Tallon L, Schatz M, Shumway M, Koo H, Salzberg SL, Schobel S, Pertea M, Pop M, White O, Barton GJ, Carlow CK, Crawford MJ, Daub J, et al: Draft genome of the filarial nematode parasite Brugia malayi. Science 2007, 317:1756-1760.

31. Hu M, Gasser RB, Abs El-Osta YG, Chilton NB: Structure and organization of the mitochondrial genome of the canine heartworm, dirofilaria immitis. Parasitology 2003, 127:37-51.

32. Keddie EM, Higazi T, Unnasch TR: The mitochondrial genome of onchocerca volvulus: sequence, structure and phylogenetic analysis. Mol Biochem Parasitol 1998, 95:111-127.

33. Park JK, Sultana T, Lee SH, Kang S, Kim HK, Min GS, Eom KS, Nadler SA: Monophyly of clade III nematodes is not supported by phylogenetic analysis of complete mitochondrial genome sequences. BMC Genomics 2011, 12:392.

34. Liu GH, Wu CY, Song HQ, Wei SJ, Xu MJ, Lin RQ, Zhao GH, Huang SY, Zhu $\mathrm{XQ}$ : Comparative analyses of the complete mitochondrial genomes of ascaris lumbricoides and ascaris suum from humans and pigs. Gene 2012, 492:110-116.

35. Jex AR, Waeschenbach A, Hu M, van Wyk JA, Beveridge I, Littlewood DT, Gasser RB: The mitochondrial genomes of ancylostoma caninum and bunostomum phlebotomum-two hookworms of animal health and zoonotic importance. BMC Genomics 2009, 10:79.

36. Liu GH, Wang SY, Huang WY, Zhao GH, Wei SJ, Song HQ, Xu MJ, Lin RQ, Zhou DH, Zhu XQ: The complete mitochondrial genome of galba pervia (gastropoda: mollusca), an intermediate host snail of fasciola spp. PLoS One 2012, 7:e42172.

37. Page RD: TREEVIEW: an application to display phylogenetic trees on personal computers. Comput Appl Biosci 1996, 12:357-358.

38. Kim KH, Eom KS, Park JK: The complete mitochondrial genome of anisakis simplex (ascaridida: nematoda) and phylogenetic implications. Int J Parasitol 2006, 36:319-328.

39. Okimoto R, Macfarlane JL, Clary DO, Wolstenholme DR: The mitochondrial genomes of two nematodes, caenorhabditis elegans and ascaris suum. Genetics 1992, 130:471-498.

40. Li MW, Lin RQ, Song $H Q$, Wu XY, Zhu XQ: The complete mitochondrial genomes for three toxocara species of human and animal health significance. BMC Genomics 2008, 9:224

41. Lavrov DV, Brown WM: Trichinella spiralis mtDNA: a nematode mitochondrial genome that encodes a putative ATP8 and normally structured tRNAS and has a gene arrangement relatable to those of coelomate metazoans. Genetics 2001, 157:621-637.

42. Lin RQ, Liu GH, Zhang Y, D'Amelio S, Zhou DH, Yuan ZG, Zou FC, Song HQ Zhu XQ: Contracaecum rudolphii B: gene content, arrangement and composition of its complete mitochondrial genome compared with anisakis simplex s.l. Exp Parasitol 2012, 130:135-140.

43. Lin RQ, Liu GH, Hu M, Song HQ, Wu XY, Li MW, Zhang Y, Zou FC, Zhu XQ: Oesophagostomum dentatum and oesophagostomum quadrispinulatum: characterization of the complete mitochondrial genome sequences of the two pig nodule worms. Exp Parasitol 2012, 131:1-7.

44. Liu GH, Gasser RB, Su A, Nejsum P, Peng L, Lin RQ, Li MW, Xu MJ, Zhu XQ: Clear genetic distinctiveness between human- and pig-derived trichuris based on analyses of mitochondrial datasets. PLoS Negl Trop Dis 2012, 6:e1539.

45. Liu GH, Wang Y, Xu MJ, Zhou DH, Ye YG, Li JY, Song HQ, Lin RQ, Zhu XQ: Characterization of the complete mitochondrial genomes of two whipworms trichuris ovis and trichuris discolor (nematoda: trichuridae). Infect Genet Evol 2012, 12:1635-1641.

46. Iorio R, Slapeta J, Otranto D, Paoletti B, Giangaspero A, Traversa D: Phylogenetic relationships of habronema microstoma and habronema muscae (spirurida: habronematidae) within the order spirurida inferred 
using mitochondrial cytochrome c oxidase subunit 1 (cox1) gene analysis. Parasitol Res 2009, 104:979-984.

47. De Ley P, Blaxter M: Systematic position and phylogeny. In The Biology of Nematodes. Edited by Lee DL. London and New York: Taylor \& Francis; 2002:1-30.

48. Nadler SA, Carreno RA, Mejía-Madrid H, Ullberg J, Pagan C, Houston R, Hugot JP: Molecular phylogeny of clade III nematodes reveals multiple origins of tissue parasitism. Parasitology 2007, 134:1421-1442.

doi:10.1186/1756-3305-6-45

Cite this article as: Liu et al:: Characterization of the complete

mitochondrial genome of Spirocerca lupi: sequence, gene organization and phylogenetic implications. Parasites \& Vectors 2013 6:45.

\section{Submit your next manuscript to BioMed Central and take full advantage of:}

- Convenient online submission

- Thorough peer review

- No space constraints or color figure charges

- Immediate publication on acceptance

- Inclusion in PubMed, CAS, Scopus and Google Scholar

- Research which is freely available for redistribution 